\title{
7: 75576574-75578263
}

National Cancer Institute

\section{Source}

National Cancer Institute. 7: 75576574-75578263. NCI Thesaurus. Code C42496.

Physical location of HSPB1_Gene 